ORIGINAL RESEARCH

\title{
Real-World Budget Impact of Listing a Biosimilar of Rituximab
}

\author{
Arnaud Boidart, Martin Darveau, Nicole Déry, and Marie-Claude Racine
}

\begin{abstract}
Background: The approval of new biosimilars by national health agencies is expected to generate significant cost savings for health care systems. This is particularly the case with the biosimilar of rituximab approved for the Canadian market in 2019. However, several uncertainties remain regarding utilization of this agent.
\end{abstract}

Objectives: To determine the proportion of total annual drug expenses for each indication for rituximab in the hospital setting and to determine potential savings related to introduction of a biosimilar.

Methods: A budget impact analysis was performed through 3 real-world scenarios, based on data obtained from a large university teaching hospital for a 12-month period.

Results: This study involved data for 420 patients. Annual expenses for rituximab for all indications represented $7.7 \%$ of total annual drug spending for the hospital, of which $5.0 \%$ was related specifically to indications approved by Health Canada. More than $6 \%$ of the annual drug expenses was attributable to the use of rituximab for oncologic indications, including 1.8\% for uses not approved by Health Canada. Overall, each $10 \%$ reduction in the price of a biosimilar of rituximab (relative to the reference rituximab) would result in annual savings of about $0.8 \%$ of total drug expenses in the hospital if a biosimilar was used for all real-world indications, whether approved by Health Canada or not.

Conclusions: The introduction of a biosimilar of rituximab to the Canadian market would generate significant savings. To properly assess the potential savings that this agent could generate in the limited budget environment of a hospital, it seems important to consider all of the indications for which it could be used.

Keywords: biosimilar, rituximab, budget impact analysis, hospital setting, real-world analysis

Can J Hosp Pharm. 2020;73(1):13-18

\section{RÉSUMÉ}

Contexte : On s'attend à ce que l'approbation de médicaments biosimilaires par les agences de santé nationales génèrent des économies importantes pour les systèmes de soins de santé. C'est particulièrement le cas pour le biosimilaire du rituximab approuvé pour le marché canadien en 2019. Cependant, plusieurs incertitudes demeurent quant à son utilisation.

Objectifs : Déterminer la proportion des dépenses pour chaque indication du rituximab par rapport à la dépense totale annuelle en médicaments dans un contexte hospitalier et déterminer les économies potentielles liées à l'introduction d'un biosimilaire.

Méthode : Une analyse d'impact budgétaire a été réalisée à partir de trois scénarios basés sur des données obtenues dans un grand centre hospitalier universitaire sur une période de 12 mois.

Résultats : Cette étude a examiné les données de 420 patients. Les dépenses annuelles relatives au rituximab, toutes indications confondues, représentaient 7,7 \% des dépenses annuelles totales de l'hôpital. De cellesci, $5 \%$ étaient liées en particulier aux indications approuvées par Santé Canada. Plus de $6 \%$ des dépenses annuelles en médicaments étaient imputables à l'utilisation du rituximab à des fins oncologiques, y compris $1,8 \%$ pour des utilisations que Santé Canada n'a pas approuvées. De manière générale, chaque réduction de $10 \%$ du prix d'un produit biosimilaire du rituximab (parent du rituximab référence) entraînerait des économies annuelles d'environ $0,8 \%$ du total des dépenses en médicaments dans cet hôpital si les produits biosimilaires étaient utilisés pour toutes les indications, qu'elles soient approuvées ou non par Santé Canada.

Conclusions : L'introduction d'un biosimilaire du rituximab sur le marché canadien engendrerait des économies importantes. Lévaluation adéquate des économies générées par un biosimilaire pour un hôpital ayant un budget limité nécessite la prise en compte de toutes les indications pour lesquelles il pourrait être utilisé.

Mots-clés : biosimilaire, rituximab, analyse d'impact budgétaire, environnement hospitalier, données en situation réelle 


\section{INTRODUCTION}

Controlling drug expenses is an important issue for hospitals. Continual efforts are made by clinical teams to offer the best treatment at the lowest cost. Indeed, hospital pharmacies are constantly working to put in place mechanisms to optimally manage drug costs. In recent years, actions undertaken at both clinical and administrative levels may have prevented annual drug expenses from exceeding the allocated annual drug budget in some hospitals. Nowadays, hospitals are confronted with legislative and administrative considerations that have changed the environment in which pharmacy departments are operating in the province of Quebec. As a result, drug-related spending will become increasingly difficult for hospitals to control.

The arrival of some biosimilars on the Canadian market in the coming years may allow some control of drug expenses in the hospital setting. However, several uncertainties remain regarding utilization of these agents. A biosimilar is evaluated by legal authorities using thorough and rigorous analyses to confirm its structure, function, clinical efficacy, and safety are similar to those of its originator biological. ${ }^{1,2}$ However, there are many practical considerations, such as interchangeability, substitution, indication extrapolation, and logistics of product use and reimbursement, that may affect willingness to use a biosimilar for a particular indication. ${ }^{3}$ More importantly, the use of a biosimilar is linked to its indications approved by Health Canada. However, scientific evidence might justify use of the reference product for some indications for which Health Canada has not granted approval, and the propensity of clinicians to prescribe a biosimilar for these non-approved indications is an important issue in the hospital setting. 4,5

When a drug enters the Canadian market, the Patented Medicine Prices Review Board (PMPRB) generates a budget impact analysis. In most cases, this analysis estimates the economic effect of using the drug for Health Canada-approved indications. Hence, for some medications, this analysis cannot be applied "as is" to assess the impact on a hospital's budget, because the drug may be used for other conditions that have not been approved by Health Canada. This is particularly the case for the licensed biologic rituximab (Rituxan ${ }^{\circledR}$, Hoffmann-La Roche Ltd, Mississauga, Ontario). ${ }^{6-9}$

Rituximab is a chimeric monoclonal antibody that specifically binds to the CD20 transmembrane antigen on mature pre-B and B lymphocytes. It is approved by Health Canada for the treatment of non-Hodgkin lymphoma, rheumatoid arthritis, chronic lymphocytic leukemia, granulomatosis with polyangiitis (Wegener granulomatosis), and microscopic polyangiitis. ${ }^{10}$ However, data may also support its use for other conditions, ${ }^{11}$ such as immune thrombocytopenic purpura, ${ }^{12-14}$ autoimmune hemolytic anemia, ${ }^{15}$ glomerulonephritis, ${ }^{16}$ and (particularly) some oncological conditions, including Waldenstrom macroglobulinemia ${ }^{17}$ and malignancies other than low-grade or follicular
non-Hodgkin lymphoma. ${ }^{18,19}$ Indeed, rituximab has been identified as one of the most cost-generating drugs in our hospital, a large university teaching hospital in the province of Quebec, representing about $15 \%$ of annual expenses for drugs used in oncology and about $7.7 \%$ of total annual expenses for drugs.

The Biosimilars Initiative ${ }^{20}$ was recently launched in the province of British Columbia. Under this initiative, the plan was to switch patients using etanercept, infliximab, or insulin glargine to biosimilar versions by November 25, 2019. As a result, British Columbia PharmaCare will cover costs only for the biosimilar versions. Other jurisdictions may decide to apply a similar policy, possibly extending it to all biosimilars, including those used in hospitals. Moreover, government authorities may even decide to completely delist the reference product. This could have an important effect on the management of these drugs in the hospital setting and could be of concern, particularly in oncology.

The current study was undertaken to explore how the arrival of a biosimilar of rituximab on the Canadian market could result in savings in the hospital setting, based on the indications for which it is likely to be used in the real world. This article should provide useful insights to anticipate future budget impacts, whether all uses would be linked to a preferred reimbursement policy or whether the decision to prescribe the reference product for some indications would be at the clinician's discretion.

\section{METHODS}

This study was conducted at the Centre hospitalier universitaire (CHU) de Québec-Université Laval, a large university hospital centre with 1263 beds. It is the largest hospital in the province of Quebec and one of the largest hospitals in Canada, serving a population of nearly 2 million. It offers a complete range of general, specialized, and ultra-specialized care and services. All adult patients (age $\geq 18$ years) who received rituximab at the CHU de Québec-Université Laval were identified during 12 consecutive months (January 1 to December 31, 2016). For that period, the average dose (mg) per patient, the average number of doses per patient, the total number of doses, and the average total amount administered (mg) per patient were calculated. The therapeutic indications were determined and divided into 2 categories: indications approved by Health Canada and other uses. These indications were then grouped according to the following medical specialties: hematology, immunology, infectious diseases, nephrology, neurology, oncology, and rheumatology. The total drug cost of rituximab was calculated for each patient over the 12 -month period and reported by indication. Because rituximab expenses remained stable from 2016 to 2019 and no new indication was authorized in the study hospital during this period, budget impact analyses were carried out using 2019 drug expense data (for April 1, 2018, to March 31, 2019). The proportion of annual expenses of rituximab for each therapeutic use was calculated in relation to total annual drug expenses. 
Unlike pharmacoeconomic studies, budget impact analysis considers only drug cost. Therefore, no safety or efficacy data were taken into account in this analysis. Moreover, because both products have the same concentration and volume, there was no cost accounting for waste due to incomplete use of vials. In other words, under this analysis, one vial of the biosimilar was assumed to replace one vial of the reference product.

Regarding market share, various scenarios were considered. The first scenario reflects the situation in which the biosimilar of rituximab would benefit from a preferred reimbursement policy and would capture the whole market of the reference rituximab for $100 \%$ of the indications recognized by Health Canada in the hospital setting. The second scenario evaluates the additional budget impact of using a biosimilar of rituximab for each non-approved indication, grouped by medical specialties. Finally, the third scenario describes the situation in which the biosimilar of rituximab would replace the reference rituximab for all indications and uses, whether approved by Health Canada or not.

Summary statistics are presented for all variables. Numbers of patients and means with standard deviations (SDs) are displayed for continuous variables when the assumptions of normal distribution of data were met. Frequencies and percentages are provided for categorical variables.

\section{RESULTS}

A total of 436 patients were identified as having had a prescription for rituximab between January 1 and December 31, 2016. Six of these patients were excluded from the analysis because their data were incomplete, and 10 patients who were less than 18 years of age were also excluded. As a result, data for 420 patients were included in the analysis. The mean age of patients was 63.6 (SD 13.7) years, and 237 (56\%) of the patients were men.

Table 1 shows the therapeutic uses for which the reference rituximab was administered in the study hospital and the proportion of spending for each indication. The indications approved by Health Canada accounted for $59.8 \%$ of cases. Only 1 patient $(0.2 \%)$ received rituximab for treatment of rheumatoid arthritis, which might seem to indicate that the field of rheumatology was underrepresented in the analysis. However, this did not affect the external validity, because rituximab is usually administered outside the hospital setting for this indication. Other (non-approved) uses represented $40.2 \%$ of the cases.

Overall, oncologic indications represented the vast majority of the cases $(80.7 \%)$, including $58.6 \%$ for indications approved by Health Canada and $22.1 \%$ for indications without Health Canada approval but supported by the literature. Several other

\section{Table 1. Therapeutic Uses of and Spending on Rituxan $®$ in the Study Hospital}

\begin{tabular}{|c|c|c|c|c|c|}
\hline \multirow[b]{2}{*}{ Therapeutic Use } & \multirow[b]{2}{*}{ No. (\%) of Patients } & \multirow[b]{2}{*}{$\begin{array}{c}\text { Dose per } \\
\text { Patient }(\mathrm{mg}) \\
(\text { Mean } \pm \text { SD) }\end{array}$} & \multirow[b]{2}{*}{$\begin{array}{c}\text { No. of Doses } \\
\text { per Patient } \\
\text { (Mean } \pm \text { SD) }\end{array}$} & \multicolumn{2}{|c|}{ Annual Expenses } \\
\hline & & & & $\begin{array}{l}\% \text { of Total } \\
\text { Rituxan® }{ }^{\circledR} \\
\text { Spending }\end{array}$ & $\begin{array}{c}\% \text { of Total } \\
\text { Drug } \\
\text { Spending }\end{array}$ \\
\hline \multicolumn{6}{|l|}{$\begin{array}{l}\text { Indications approved by } \\
\text { Health Canada }\end{array}$} \\
\hline Total approved indications & $251(59.8)$ & $701.8 \pm 106.6$ & $4.5 \pm 2.2$ & 64.3 & 5.0 \\
\hline Wegener granulomatosis & $4 \quad(1.0)$ & $925.0 \pm 129.9$ & $3.5 \pm 0.5$ & 1.0 & 0.1 \\
\hline Oncology & $246(58.6)$ & $697.0 \pm 100.6$ & $4.5 \pm 2.2$ & 63.1 & 4.9 \\
\hline CLL & $33(7.9)$ & $793.4 \pm 150.7$ & $4.8 \pm 2.1$ & 10.6 & 0.8 \\
\hline NHL, low grade & 14 (3.3) & $659.4 \pm 79.8$ & $4.8 \pm 2.4$ & 3.5 & 0.3 \\
\hline NHL, diffuse large B-cell & $111(26.4)$ & $680.6 \pm 81.8$ & $4.4 \pm 2.2$ & 26.9 & 2.1 \\
\hline NHL, follicular & $88(21.0)$ & $687.4 \pm 78.5$ & $4.5 \pm 2.2$ & 22.1 & 1.7 \\
\hline Rheumatoid arthritis & $1 \quad(0.2)$ & $1000.0 \pm 0.0$ & $2.0 \pm 0.0$ & 0.2 & NS \\
\hline \multicolumn{6}{|l|}{$\begin{array}{l}\text { Non-approved uses } \\
\text { (by medical specialty) }\end{array}$} \\
\hline Total non-approved uses & $169(40.2)$ & $739.3 \pm 149.4$ & $3.7 \pm 2.3$ & 35.7 & 2.8 \\
\hline Hematology & $27 \quad(6.4)$ & $681.5 \pm 77.0$ & $3.8 \pm 1.1$ & 5.6 & 0.4 \\
\hline Autoimmune hemolytic anemia & $5 \quad(1.2)$ & $689.0 \pm 104.1$ & $3.4 \pm 1.2$ & 0.9 & $<0.1$ \\
\hline $\begin{array}{l}\text { Immune thrombocytopenic } \\
\text { purpura }\end{array}$ & $17 \quad(4.0)$ & $684.4 \pm 74.8$ & $3.8 \pm 1.1$ & 3.6 & 0.28 \\
\hline Immunology & $7 \quad(1.7)$ & $846.4 \pm 186.0$ & $2.4 \pm 1.2$ & 1.1 & 0.1 \\
\hline Infectious diseases & $4 \quad(1.0)$ & $695.5 \pm 117.2$ & $3.8 \pm 1.6$ & 0.9 & 0.1 \\
\hline Nephrology (glomerulonephritis) & $29(6.9)$ & $965.5 \pm 126.7$ & $1.8 \pm 0.7$ & 4.0 & 0.3 \\
\hline Neurology & $8 \quad(1.9)$ & $789.5 \pm 173.4$ & $2.9 \pm 2.1$ & 1.4 & 0.1 \\
\hline Oncology & $93(22.1)$ & $676.0 \pm 76.7$ & $4.4 \pm 2.6$ & 22.6 & 1.8 \\
\hline $\begin{array}{l}\text { NHL malignancies other than } \\
\text { low-grade or follicular }\end{array}$ & $88(21.0)$ & $677.1 \pm 76.3$ & $4.4 \pm 2.6$ & 21.5 & 1.7 \\
\hline Rheumatology & $1 \quad(0.2)$ & $652.0 \pm 0.0$ & $4.0 \pm 0.0$ & 0.2 & NS \\
\hline Total & $420(100)$ & $716.9 \pm 126.9$ & $4.2 \pm 2.3$ & 100 & 7.7 \\
\hline
\end{tabular}

$\mathrm{CLL}$ = chronic lymphocytic lymphoma, NHL = non-Hodgkin lymphoma, NS = not significant. 
uses were identified. Among these, glomerulonephritis (6.9\%) and idiopathic thrombocytopenic purpura (4.0\%) were the most frequent. Most of the remaining indications represented less than $1 \%$ of cases each.

Annual expenses of rituximab for all indications represented $7.7 \%$ of total annual drug spending. Rituximab-related spending for indications approved by Health Canada represented 5\% of total annual drug expenses. About $6.7 \%$ of annual expenses was attributable to the use of rituximab for oncologic indications, including $1.8 \%$ for uses not approved by Health Canada. Approximately $35 \%$ of annual expenses of rituximab were for other off-label uses, including $22.6 \%$ in oncology, $5.6 \%$ in hematology, and $4 \%$ in nephrology.

Table 2 shows the percentage savings from total annual drug expenses for each $10 \%$ reduction in the price of a biosimilar of rituximab relative to the price of the reference rituximab. Scenario 1 presents the situation in which a biosimilar of rituximab is used in the hospital setting only for indications approved by Health Canada. In this situation, each $10 \%$ decrease would generate annual savings of approximately $0.5 \%$ on total annual drug expenses. According to this scenario, the expected annual savings for a hospital having an annual drug expense of $\$ 50$ million would be $\$ 248,809$ per year (Table 3 ).

Scenario 2 shows the additional savings that would be generated with use of a biosimilar of rituximab not only for indications approved by Health Canada but also for other indications, based on real-world data observed in our university teaching hospital. For example, use of a biosimilar of rituximab for non-approved oncology indications would generate additional savings of $0.175 \%$ of total annual expenses for each $10 \%$ difference in price compared with the reference rituximab (Table 2 and Table 3).

Within the third scenario, overall, each $10 \%$ reduction in the price of a biosimilar of rituximab relative to Rituxan ${ }^{\circledR}$ would result in annual savings of about $0.78 \%$ of total annual drug expenses for this large university teaching hospital in the province of Quebec, if the biosimilar was used for all real-world indications, whether approved by Health Canada or not (Table 2).

\section{DISCUSSION}

Drug expenses represent a significant part of a hospital's budget. Despite the arrival of increasingly expensive drugs on the Canadian market, hospital pharmacies have, up to now, been able to control drug expenses. The arrival of generic oncology drugs and various clinical and administrative interventions have helped to offset the increase in prices. As a result, a slight decrease in total drug expenses was observed in our hospital from 2015 to 2017. However, among drugs representing a significant proportion of overall annual expenses, no generic drugs are anticipated on the Canadian market in the next few years. ${ }^{21}$ Hence, the growing presence of more expensive drugs is no longer counterbalanced,
Table 2. Impact of a Biosimilar of Rituximab on
Total Annual Drug Expenses for a University
Teaching Hospital in the Province of Quebec

Scenario

$\%$ Saving*

Scenario 1: Biosimilar of rituximab capturing 0.50

market of reference rituximab for all indications

approved by Health Canada

Scenario 2: Scenario 1 + savings due to biosimilar

of rituximab replacing reference rituximab for

each non-approved use (by medical specialty)

Oncology

0.50

Hematology

0.175

Nephrology

0.043

Immunology

0.031

Neurology

0.008

Infectious diseases

0.012

Rheumatology

0.007

Scenario 3: Biosimilar of rituximab replacing

reference rituximab for all indications and uses,

whether approved by Health Canada or not

*Savings in total annual drug expenses for each $10 \%$ reduction in the price of a biosimilar of rituximab, relative to the price of the reference drug, Rituxan®

\section{Table 3. Annual Savings with a $10 \%$ Reduction in Price of a Biosimilar of Rituximab Compared with Price of Rituxan $\AA^{*}$}

\begin{tabular}{lc} 
Scenario & Annual Saving \\
\hline $\begin{array}{l}\text { Scenario 1: Biosimilar of rituximab capturing } \\
\text { market of reference rituximab for all indications } \\
\text { approved by Health Canada }\end{array}$ & $\$ 248,809$ \\
\hline $\begin{array}{l}\text { Scenario 2: Scenario 1 + biosimilar of rituximab } \\
\text { replacing reference rituximab for non-approved }\end{array}$ & $\$ 248,809$ \\
uses (by medical specialty) & + \\
Oncology & $\$ 87,317$ \\
Hematology & $\$ 21,640$ \\
Nephrology & $\$ 15,376$ \\
Immunology & $\$ 4,129$ \\
Neurology & $\$ 5,317$ \\
Infectious diseases & $\$ 3,351$ \\
Rheumatology & $\$ 818$ \\
Scenario 3: Biosimilar of rituximab replacing & $\$ 386,759$ \\
reference rituximab for all indications and uses, \\
whether approved by Health Canada or not \\
*Based on hypothetical total annual drug expenses of $\$ 50$ million.
\end{tabular}

and our hospital has experienced increases in drug expenses over the past few years. Conversely, the arrival of biosimilars could help to restore the economic counterweight that was previously exerted by generic drugs in the hospital setting.

As mentioned previously, much uncertainty remains about the introduction of biosimilars on the Canadian market in terms of their utilization, but also with regard to their price and the number of molecules becoming available. As reported in 2018 by the French Healthcare Products Pricing Committee (CEPS), the price of biosimilars in France was about 20\% to $40 \%$ lower than that of the reference biologics. ${ }^{22}$ In the province of Quebec, the biosimilar of bevacizumab, Mvasi ${ }^{\mathrm{TM}}$ (Amgen Canada Inc), ${ }^{23}$ was 
recently listed, with estimated provincial savings of $\$ 34.5$ million over 3 years. ${ }^{24}$ Furthermore, over the next 3 years in Canada, the PMPRB anticipates the arrival of about 10 biosimilar products. ${ }^{25}$

Regarding the rituximab situation specifically, the amount of savings that could be generated upon arrival of the biosimilar depends on 2 factors: price and utilization. Truxima ${ }^{\mathrm{TM}}$ (manufactured by Celltrion Healthcare Co Ltd and distributed by Teva Canada Limited ${ }^{26}$ is the first biosimilar of rituximab to become commercially available in Canada. A review was published in November 2019 by the Institut national d'excellence en santé et en services sociaux (INESSS), the health technology assessment body in the province of Quebec. ${ }^{27}$ The indications approved by Health Canada do not include severe granulomatosis with polyangiitis (Wegener granulomatosis) or microscopic polyangiitis in adults, and it is unknown whether clinicians will adopt this biosimilar for non-approved indications. Rituxan ${ }^{\circledR}$ is approved by Health Canada for treatment of Wegener granulomatosis, but this indication represents only $1.0 \%$ of Rituxan ${ }^{\circledR}$ use in the hospital setting, corresponding to $0.1 \%$ of total annual drug expenses (Table 1). Therefore, using a biosimilar of rituximab for this indication would not have a significant impact on annual drug spending, whereas using a biosimilar for non-approved uses in oncology could generate more important savings. Moreover, because of the uncertainty surrounding the amplitude of the price reduction associated with the biosimilar, in our analysis we considered several possible situations, represented by 3 scenarios. For example, every $10 \%$ price reduction relative to the reference product rituximab would generate savings according to the extent of uses in the hospital (Table 3).

\section{Limitations}

The current analysis was based on data collected for patients who received the reference product (rituximab) in 2016. It is worth mentioning that subsequent validations have shown that the proportion of rituximab used for each indication category has remained stable in the following years, given that no new indications have been approved. However, in the near future, the overall number of doses of rituximab administered intravenously may change, because a subcutaneous formula of rituximab has recently been approved by Health Canada. ${ }^{28,29}$ Hence, savings estimated in the current analysis for one specific oncologic indication may be greater than what will be realized following listing of the subcutaneous formulation. The results of our analysis should also be interpreted in the context of each jurisdiction. In particular, if a jurisdiction decides to apply a preferred reimbursement policy to the biosimilar of rituximab only for indications approved by Health Canada, scenario 1 would be applied. Hospital stakeholders and clinicians would then have to decide which part of scenario 2 they would be willing to apply in their hospital. If Rituxan ${ }^{\circledR}$ is completely delisted, scenario 3 would apply, with the biosimilar being used for all indications, whether approved by Health Canada or not. Such a policy could be implemented gradually, with Rituxan therapy continuing for those who are already receiving it and covering the biosimilar only for treatment-naive patients. However, given the nature of the indications and their associated duration of treatment, it seems that almost all patients will be receiving the biosimilar within the 2 years following implementation of the policy. Hence, savings estimated for the first few years will be overestimated. Finally, annual savings in our analysis rely mainly on the fact that, for oncology indications and treatment in the province of Quebec, rituximab must be administered in the hospital setting, with financing by the hospital; as such, the estimated savings would not be generalizable to all other jurisdictions.

\section{CONCLUSION}

The use of rituximab is an important aspect of total annual drug expenses for university teaching hospitals. Real-world data from one such hospital show that rituximab is prescribed for several therapeutic indications, but it is not known to what extent clinicians would be willing to prescribe a biosimilar of rituximab for uses that are not approved by Health Canada. The arrival of a biosimilar of rituximab on the Canadian market would generate significant savings. To properly assess the potential savings that this agent might generate in the context of a hospital's limited budget, it seems important to consider all of the indications for which it could be used.

\section{References}

1. Guidance document. Information and submission requirements for biosimilar biologic drugs. Ottawa (ON): Health Canada, Health Products and Food Branch; 2010 Mar 5 [revised 2016 Nov 14; cited 2019 Feb 10]. Available from: https://www.canada.ca/content/dam/hc-sc/migration/hc-sc/dhp-mps/ alt_formats/pdf/brgtherap/applic-demande/guides/seb-pbu/seb-pbu-2016eng.pdf

2. Biosimilar biologic drugs in Canada: fact sheet. Ottawa $(\mathrm{ON})$ : Health Canada; 2019 [cited 2020 Feb 2]. Available from: https://www.canada.ca/ content/dam/hc-sc/migration/hc-sc/dhp-mps/alt_formats/pdf/brgtherap/ applic-demande/guides/biosimilars-biosimilaires-qa-qr-eng.pdf

3. Stevenson JG, Popovian R, Jacobs I, Hurst S, Shane LG. Biosimilars: practical considerations for pharmacists. Ann Pharmacother. 2017;51(7):590-602.

4. Li E, Lobaina E. Application of the FDA biosimilar extrapolation framework to make off-label determinations. J Manag Care Spec Pharm. 2017;23(12): 1227-32.

5. Hao S, Nair JR, Moots RJ. Biosimilars: from extrapolation into off label use. Curr Pharm Des. 2017;23(44):6746-51.

6. Collongues N, de Seze J. An update on the evidence for the efficacy and safety of rituximab in the management of neuromyelitis optica. Ther $A d v$ Neurol Disord. 2016;9(3):180-8.

7. Coppo P. Management of thrombotic thrombocytopenic purpura. Transfus Clin Biol. 2017;24(3):148-53.

8. Stieglbauer K, Pichler R, Topakian R. 10-year-outcomes after rituximab for myasthenia gravis: efficacy, safety, costs of inhospital care, and impact on childbearing potential. J Neurol Sci. 2017;375:241-4.

9. Kronbichler A, Windpessl M, Pieringer H, Jayne DRW. Rituximab for immunologic renal disease: what the nephrologist needs to know. Autoimmun Rev. 2017;16(6):633-43.

10. Rituxan ${ }^{\circledR}$ rituximab $10 \mathrm{mg} / \mathrm{mL}$ intravenous infusion [product monograph]. Submission control number 221231. Mississauga (ON): Hoffmann-La Roche Ltd; 2000 [cited 2019 Feb 11]. Available from: www.rochecanada.com/ content/dam/roche_canada/en_CA/documents/Research/Clinical 
This single copy is for your personal, non-commercial use only.

For permission to reprint multiple copies or to order presentation-ready copies for distribution, contact CJHP at publications@cshp.ca

TrialsForms/Products/ConsumerInformation/MonographsandPublic Advisories/Rituxan/RituxanIV_PM_E.pdf

11. Zarkali A, Karageorgopoulos DE, Rafailidis PI, Falagas ME. Frequency of the off-label use of monoclonal antibodies in clinical practice: a systematic review of the literature. Curr Med Res Opin. 2014;30(3):471-80.

12. Auger S, Duny Y, Rossi JF, Quittet P. Rituximab before splenectomy in adults with primary idiopathic thrombocytopenic purpura: a meta-analysis. $\mathrm{BrJ}$ Haematol. 2012;158(3):386-98.

13. Ghanima W, Khelif A, Waage A, Michel M, Tjønnfjord GE, Romdhan NB, et al. Rituximab as second-line treatment for adult immune thrombocytopenia (the RITP trial): a multicentre, randomised, double-blind, placebo-controlled trial. Lancet. 2015:385(9978):1653-61.

14. Arnold DM, Heddle NM, Carruthers J, Cook DJ, Crowther MA, Meyer $\mathrm{RM}$, et al. A pilot randomized trial of adjuvant rituximab or placebo for nonsplenectomized patients with immune thrombocytopenia. Blood. 2012; 119(6):1356-62.

15. Barcellini W. Current treatment strategies in autoimmune hemolytic disorders. Expert Rev Hematol. 2015;8(5):681-91.

16. Walters G, Willis NS, Craig JC. Interventions for renal vasculitis in adults. Cochrane Database Syst Rev. 2015;(9):CD003232.

17. Kastritis E1, Dimopoulos MA. Current therapy guidelines for Waldenstrom's macroglobulinaemia. Best Pract Res Clin Haematol. 2016;29(2):194-205.

18. Rummel MJ, Niederle N, Maschmeyer G, Banat GA, von Grünhagen U, Losem C, et al. Bendamustine plus rituximab versus $\mathrm{CHOP}$ plus rituximab as first-line treatment for patients with indolent and mantle-cell lymphomas: an open-label, multicentre, randomised, phase 3 non-inferiority trial. Lancet. 2013;381(9873):1203-10.

19. Cheah CY, Opat S, Trotman J, Marlton P. Front-line management of indolent non-Hodgkin lymphoma in Australia. Part 2: mantle cell lymphoma and marginal zone lymphoma. Intern Med J. 2019;49(9):1070-80.

20. Biosimilars Initiative for Patients [website]. Victoria (BC): BC PharmaCare; [cited 2019 Jul 11]. Available from: https://www2.gov.bc.ca/gov/content/ health/health-drug-coverage/pharmacare-for-bc-residents/whatwe-cover/drug-coverage/biosimilars-initiative-patients

21. Schumock GT, Stubbings J, Wiest MD, Li EC, Suda KJ, Matusiak LM, et al. National trends in prescription drug expenditures and projections for 2018. Am J Health Syst Pharm. 2018;75(14):1023-38.

22. Rapport d'activité 2018. Paris (FR): Comité économique des produits de santé; 2019 [cited 2020 Jan 29]. Available from: https://solidaritessante.gouv.fr/IMG/pdf/ceps_rapport_d_activite_2018_20191122.pdf? fbclid=IwAR25X1YL6D4JIVf1B8V3doz-xV5Jkb2baYZg9mA6rWtj0qu4a P1MZ4JbU7I

23. Drug Products Database: MVASI [product monograph]. Amgen Canada Inc.; [cited 2020 Jan 22]. Available from: https://health-products.canada.ca/ dpd-bdpp

24. $\mathrm{MVASI}^{\mathrm{TM}}$ - cancer colorectal métastatique [avis transmis à la ministre en janvier 2019]. Québec (QC): Institut national d'excellence en santé et en services sociaux (INESSS); 2019 Feb 13 [cited 2020 Jan 22]. Available from: https://www.inesss.qc.ca/fileadmin/doc/INESSS/Inscription_medicaments/ Avis_au_ministre/Fevrier_2019/Mvasi_2019_01.pdf
25. National Prescription Drug Utilization Information System. Potential savings from biosimilars in Canada. Ottawa (ON): Patented Medicine Prices Review Board; 2016 [cited 2019 Feb 11]. Available from: www.pmprb-cepmb.gc.ca/ CMFiles/NPDUIS/2017_Conference_Posters/post_6_biosim.pdf

26. Drug Products Database: Truxima [product monograph]. Celltrion Healthcare Co Ltd; [cited 2019 Aug 15]. Available from: https://health-products. canada.ca/dpd-bdpp

27. Truxima ${ }^{\mathrm{MC}}$ - Lymphome non hodgkinien, leucémie lymphoïde chronique et polyarthrite rhumatoïde [avis transmis à la ministre en octobre 2019]. Québec (QC): Institut national d'excellence en santé et en services sociaux (INESSS); 2019 Oct [cited 2020 Feb 6]. Available from: https:// www.inesss.qc.ca/fileadmin/doc/INESSS/Inscription_medicaments/Avis_au_ ministre/Novembre_2019/Truxima_2019_10.pdf

28. Rituxan ${ }^{\circledR} \mathrm{SC}$ rituximab $120 \mathrm{mg} / \mathrm{mL}$ solution for subcutaneous injection [product monograph]. Submission control number 216448. Mississauga (ON): Hoffmann-La Roche Ltd; 2018 May 31 [cited 2019 Feb 11] Available from: www.rochecanada.com/content/dam/roche_canada/en_CA/ documents/Research/ClinicalTrialsForms/Products/ConsumerInformation/ MonographsandPublicAdvisories/RituxanSC/RituxanSC_PM_E.pdf

29. Assouline S, Buccheri V, Delmer A, Gaidano G, Trneny M, Berthillon N, et al. Pharmacokinetics, safety, and efficacy of subcutaneous versus intravenous rituximab plus chemotherapy as treatment for chronic lymphocytic leukaemia (SAWYER): a phase $1 \mathrm{~b}$, open-label, randomized controlled non-inferiority trial. Lancet Haematol. 2016;3(3):e128-38.

Arnaud Boidart, MPharm, MBA, is with the Faculty of Pharmacy of Amiens, Amiens, France.

Martin Darveau, BPharm, MSc, is with the Pharmacy Department, Centre hospitalier universitaire de Québec-Université Laval, Québec, Quebec.

Nicole Déry, BPharm, MSc, is with the Pharmacy Department, Centre hospitalier universitaire de Québec-Université Laval, Québec, Quebec.

Marie-Claude Racine, BPharm, MSc, is with the Pharmacy Department, Centre hospitalier universitaire de Québec-Université Laval, Québec, Quebec.

Competing interests: Arnaud Boidart received personal fees for shortterm internships in medical marketing (Amgen) and medical affairs (Abbvie). No other competing interests were declared.

\section{Address correspondence to:}

Martin Darveau

Centre hospitalier universitaire de Québec-Université Laval

2705, boulevard Laurier

Québec QC G1V 4G2

e-mail: martin.darveau@chudequebec.ca

Funding: None received. 